\title{
Macroeconomic Determinants of Liquidity of the Bond Market in Africa: Case Study of South Africa
}

\author{
${ }^{1}$ Forget M Kapingura*, ${ }^{2}$ Sylvanus I Ikhide \\ ${ }^{1}$ University of Fort Hare, East London, South Africa \\ ${ }^{2}$ University of Stellenbosch Business School, Cape Town, South Africa \\ *fkapingura@ufh.ac.za
}

\begin{abstract}
The importance of the bond market to the financial system and broader economy of a country cannot be underestimated. Thus this study seeks to establish the determinants of liquidity in the South African bond market using monthly data covering the period 1995 to 2009, employing the Johansen cointegration test and the Vector Error Correction Model. Empirical results reveal that there is a longterm relationship between the selected macroeconomic variables and bond market liquidity in South Africa. Based on the empirical results, it is recommended that authorities should keep inflation at low and stables levels as well as a stable currency. Of great importance in the study is the role played by foreign investors in the bond market. The positive impact of the foreign investor participation on the bond market liquidity in South Africa suggests that authorities should remove restrictions on foreign investor activities to enhance liquidity in this important market.
\end{abstract}

Keywords: Bond Market Liquidity, Johansen cointegration, Vector Error Correction Model, South Africa

\section{Introduction}

Liquidity has become an important element for the healthy functioning of the bond market. The market for government securities dominates the securities market in most African countries and thus plays an important role in providing a basis for a robust and efficient financial system as a whole. This sector contributes mostly to the transformation of savings into investment, disseminating information, managing risk, and supporting activities in other securities (Chabchitrchaidol \& Panyanukul, 2005). In addition, the yield curve which is a leading indicator of business cycle (as it provides the vital guide to the future behaviour of inflation and interest rates) has its genesis in the government bond market. However, one major constraint in this market is the issue of liquidity. There are many ways in which liquidity is defined in the literature. Gravelle (1998) defines liquidity as being "the ease with which large-size transactions can be effected without impacting market prices". Borio (2000) on the other hand describes a liquid market as one where "...transactions can take place rapidly and with little impact on price". However, the Committee on the Global Financial System (CGFS) (1999) shows that the concept of liquidity can be further elaborated in a number of dimensions. These include tightness, depth/size, resiliency, and immediacy. Despite the different definitions of liquidity, its importance to the bond market cannot be underestimated. Illiquidity in this important market is likely to cause massive price volatility and complicate the open market operations of the central bank. This arises as the transmission mechanism of monetary policy which allows the central bank to infer inflation and interest rate expectations of market participants, and contribute to the promotion of economic growth, by facilitating more efficient pricing of borrowing and lending is obscured (Mminele, 2009). In addition, the Asian Development Bank (ADB, 2005) suggests that outright purchases and repurchases of securities are important instruments of monetary policy. If market liquidity is not sufficient, central banks might not be able to provide or absorb the necessary amount of funds smoothly through their open market operations. This could produce unintended effects such as excessive price volatility. Therefore bond market liquidity provides encouragement to the tools of financial mediation, making these tools very essential as they are related to market pricing, effective borrowing and investment practises.

It is important to note that the South African bond market is relatively efficient compared to most African bond markets as indicated by the 2009 Fitch ratings. In addition, there are a number of factors which qualifies the South African bond market relative to other African bond markets. Firstly, Hove (2008) argues that Bond Exchange of South Africa (BESA) has not had any liquidation default and no claims have been made on the Guarantee Fund in its history. Secondly, Jones (2007) shows that BESA did not close its market during market disruptions such as the Russian and Asian problems in 1998 as well as the 11 September 2001 tragedy. Thirdly, the South African bond market has a turnover ratio equivalent to other 
mature markets. BESA's 2007 market performance report shows that turnover on the bond exchange reached a record R13.8 trillion, with R13 trillion occurring in government bonds. Thus, this paper seeks to investigate the determinants of liquidity in this market as this might provide some useful insights for other African countries where the bond market is still in its infancy considering that the bond market is another source of domestic financial resource mobilisation. In addition to the carry-over for other African economies, identifying the determinants of liquidity will help policy makers to focus on this segment of the economy in order to further enhance its efficiency by avoiding price volatility, encouraging macroeconomic stability and achieving long-term economic growth. The paper is organised as follows: Section II focuses on the overview of the South African bond market; Section III literature review; Section IV discusses the theoretical framework and econometric methodology used to carry out the study; Section $\mathrm{V}$ presents the empirical results from with Section VI discussing the concluding remarks.

Overview of the South African Bond Market: The South African bond market has undergone major developments since its inception. This has resulted in enhanced efficiency and safety in the market thus attracting investors to it. Due to the developments in the market, it is described (Ambrosi, 2009) as one of the leading emerging bond markets in the world. Ambrosi (2009) further indicates that the South African bond market when measured in terms of debt issued comprises but a fraction of the world's debt markets combined, yet it constitutes the lion's share of the African debt market. It boasts of a level of sophistication and efficiency that matches those of many of the bigger debt markets in the developed world. The South African bond market compares favourably to other emerging market economies in terms of outstanding bonds as shown in table 1.

Table 1: Size of Domestic bond markets at the end of 2010 (Billions of US dollars)

\begin{tabular}{llllll}
\hline Country & \multicolumn{2}{l}{$\begin{array}{l}\text { Amounts Outstanding By sector } \\
\text { and residence of Issuer }\end{array}$} & \multicolumn{2}{l}{ Changes in Stocks } \\
& $\mathbf{2 0 0 8}$ & $\mathbf{2 0 0 9}$ & $\mathbf{2 0 1 0}$ & $\mathbf{2 0 0 9}$ & $\mathbf{2 0 1 0}$ \\
\hline Australia & 639.6 & 874.9 & 1043.6 & 42.2 & 48.5 \\
Denmark & 591.1 & 691.2 & 659.9 & 95.0 & 17.8 \\
Germany & 2592.8 & 2806.7 & 2615.9 & 107.4 & 10.2 \\
Switzerland & 259.0 & 259.5 & 291.0 & -9.5 & 5.6 \\
United Kingdom & 1219.3 & 1548.8 & 1647.0 & 182.5 & 148.4 \\
South Africa & 93.8 & 140.4 & 189.0 & 6.4 & 10.0 \\
Mexico & 319.5 & 362.8 & 429.0 & 30.8 & 44.6 \\
Argentina & 66.2 & 57.3 & 58.9 & -5.3 & 3.2 \\
Malaysia & 172.7 & 189.3 & 239.9 & 14.2 & 28.9 \\
South Korea & 863.5 & 1066.1 & 1111.0 & 118.5 & 16.5 \\
Finland & 88.5 & 93.2 & 87.4 & 2.4 & 0.5 \\
Indonesia & 70.7 & 97.7 & 93.4 & 13.7 & -8.9 \\
Czech Republic & 65.2 & 80.3 & 74.2 & 12.1 & -4.6 \\
\hline
\end{tabular}

Source: Bank of International Settlements (2011)

Table 1 indicates that the size of the bond market in South Africa is relatively large compared to some of the emerging countries (Czech Republic \& Indonesia) though it is still small as compared to those of other developed countries. The South African authorities have adopted a number of initiatives to increase trading volume so as to promote market liquidity. Firstly, the appointment of primary dealers/ market makers by the government in 1998 who are involved in quoting firm prices (bid and offer) in certain government bonds improved transparency and overcame shortcomings which were inherent in the tap issue method, in which the Reserve Bank was issuing bonds on behalf of the government ${ }^{1}$. This system was flawed since the Reserve Bank in its market making role was always a net seller and the process at times conflicted with the Reserve Bank's monetary policy function. Secondly, BESA also facilitated the development of an active repo market, which has made a major contribution to the secondary market. It is argued that traders have used repos to fund their positions, hedge short positions in the capital markets, facilitate settlement and employ cash for the short-term between investment decisions. Thirdly, the Exchange developed a system in terms of which firm bid and offer prices and traded prices are

\footnotetext{
${ }^{1}$ It must be noted however that this market making role of the central bank at the initial stages of the development of the bond market facilitated the transfer of this function to commercial banks at a later stage and improved liquidity in the market.
} 
entered into a central price discovery screen which is available to all the Exchange's users. This has further improved liquidity by promoting price dissemination (Greubel, 2008).

The development of the South African bond market has mirrored developments in economic development as well as other financial markets (equity and futures). This is consistent with Adelegan (2009), who suggest that the growth in the bond market and equity market have contributed to the growth of the futures market in South Africa by facilitating the introduction of a number of equity and bond market related instruments. This shows that a well-developed financial system with all financial markets operating promote economic growth as each segment plays its role in terms of mitigating risks, resource mobilization and efficient allocation of scarce resources resulting in sustainable economic growth.

Market Structure and Organisation: The market structure of the South African bond market has been another important factor contributing to the liquidity of its bond market. BESA offers a secure and efficient dealing environment for the products for which it was created. These are rand denominated debt securities mainly bonds as well as money market securities (issued by government, public enterprises and the corporate sector) and derivatives. However, its main product is central government bond (Faure, 2007). BESA is structured in a way to create a clear distinction between users (issuers and members of the market associations), rights holders (affiliated to shareholders) and stakeholders (the SARB, the regulators, the investment community and the Debt Issuer's Association (DIA)). Jointly, stakeholders form part of the stakeholder forum, whose aim is to make sure that BESA and the market associations fulfil their license requirements and that the market functions effectively in terms of good market practice (BESA, 2007). Figure 2:1 shows the structure of BESA as of 2008.

\section{Figure 1: Market Structure}

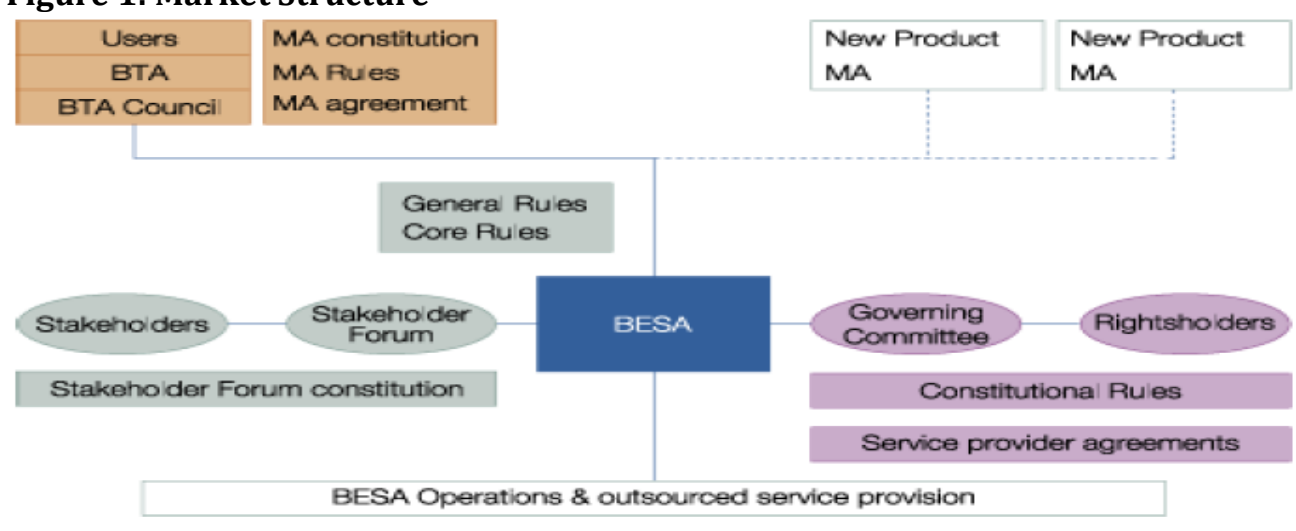

Key:

BTA-Bond Trader's Association

MA- Market Association

Source: Hove (2008)

Market associations are groups of users that contract with BESA for a package of tailor made services. This means that users of the exchange benefit from the ability to choose how to trade and with whom, as well as how they wish to influence and develop the market (Hove, 2008:43).The market associations are divided into three main categories and are governed by their own rules which are compliant and consistent with the core rules of BESA. These categories are:

- The Bond Traders Associations (BTA), formed by bond traders to represent the welfare of the trading community in South Africa.

- The Derivatives Traders Association (DTA): for the interests and views of firms registered to trade BESA-listed derivative instruments.

- The Debt Issuers Association (DIA): to guide and steer transformation within the markets by dealing with both operational and strategic issues (Hove, 2008).

Trading and Settlement: In the South African bond market deal execution takes place via two trading systems. According to Faure (2007) these are:

- Telephone-screen trading. With this system, market makers place indication rates on information vendor (IV) screens such as Reuters Monitor Service and deals are negotiated and consummated 
over the phone. This is therefore a quote-driven market in which market makers quote buying and selling rates.

- Screen-telephone trading. In this system the interdealer brokers quote firm rates on IV screens, and the telephone is used by members of the exchange to take (buy) or give (sell) that is to confirm the transaction with the interdealer broker.

Deals by members of BESA are reported to BESA and confirmed via the electronic system called BTB which is the trade capturing system. This system is also designed to be a price discovery system. Prior to the current system, the floor trading method also called open-outcry trading was the method in use up to 1998 (Faure, 2007). As for settlement, bond deals through BESA are conducted on a netted and $\mathrm{T}+3$ rolling settlement systems. The institutions involved in clearing and settlement are a clearing house (STRATE), a central securities depository (STRATE) and a settlement agent system. The Exchange offers protection from settlement failure and tainted scrip risk through its Guaranteed Fund, and members' compulsory fidelity cover provides protection against fraud/ theft perpetrated by employees of a member firm (Faure, 2007).

The regulatory framework in South Africa has been another major important ingredient towards the development of the bond market. The South African bond market has experienced major changes in its regulation. This includes the move from Over the Counter (OTC) markets to exchange-traded market. Exchange driven-market eliminates or lessens a number of risks inherent in OTC markets. These risks include counterparty risk, settlement risk, broker-dealer fraud risk and tainted scrip risk ${ }^{2}$. The elimination or lessening of risk goes hand-in-hand with efficiency of trading. Faure (2008:92) attests that the elimination or lessening of risk and efficiency of trading maybe subsumed under " $a$ secure and efficient dealing environment". Faure goes on to point out that such an environment attracts more participants, both local and foreign, which leads to higher turnover, thus higher liquidity and ultimately to efficient price discovery, and possibly lower transaction costs.

Central to BESA operations, has been its regulatory and supervisory obligations. These obligations were met by the Market Regulation Division (MRD), which was established in 2004 as a totally ring-fenced division separate from BESA's commercial operations. However, with the acquisition of BESA, the MRD has been integrated into the Surveillance Division and the Clearing and Settlement Division of the JSE (BESA, 2010).BESA has ensured that the rules of the exchange are $\mathrm{G}_{30}$-compliant and continuously strives to formulate its rules against international best practice (BESA, 2005:14). This has improved the efficiency and effectiveness of the market and hence liquidity. This has also encouraged both local and foreign investors to participate in the bond market.

\section{Literature Review}

A number of studies have been carried out to establish the determinants of liquidity in bond markets. However, the conclusions vary from market to market. According to Borio (2000) the increasing interest in liquidity stems from the need for an efficient financial system. Choudhry (2010) describes liquidity as an important factor underpinning the smooth functioning of the financial system and conditioning the daily activities of economic agents, including pricing, trading and risk management. Das et al. (2003) describes the importance of liquidity to markets as oxygen is to humans as it is only noticeable by its absence. The need to establish the determinants of bond market liquidity has attracted a number of empirical studies. Of the available studies, Chabchitrchaidol and Panyanukul (2005) looked at the key determinants of liquidity in the Thai bond market, measured by bid-ask spreads on government bonds. Empirical results using EGARCH estimation revealed that a rise in the volatility of bond yields leads to a larger bid-ask spread. The authors concluded that volatility is negatively related to bond market liquidity.

On another study Garcia (1989) argue that monthly stance of the Federal Reserve Bank can affect liquidity by altering the terms of margin borrowing and alleviating the borrowing constrains of dealers. The author found that monetary expansions are associated with increased liquidity during crisis periods. This was consistent with Fujimoto (2004) who also discovered that monetary variables are significant

\footnotetext{
${ }^{2}$ Counterparty risk is reduced as the investor deals with a broker-dealer who is under constant surveillance; Settlement risk refers to deals being settled efficiently by the exchange through a deal booking system, BTB here in South Africa; Broker-dealer fraud risk is reduced because of surveillance and tainted scrip risk is eliminated in a dematerialised environment.
} 
drivers of securities market liquidity. This suggests therefore that monetary policy has an impact on bond market liquidity. Goyenko, Subrahmanyam and Ukhov (2011) looked at the term structure of bond market liquidity of the US from November 1967 to December 2005 using Vector Autoregression analysis on illiquidity of three maturity ranges, thus short, medium and long. Empirical results indicated that onthe-run and off-the-run illiquidity has different time series determinants. On-the-run illiquidity across all maturities is largely affected by volatility. On the other hand off-the-run illiquidity is driven by inflation, monetary policy surprises, bond returns and volatility. Overall, off-the-run illiquidity is affected by a larger set of economic variables. Their results were consistent with the idea that the effect of macroeconomic variables on dealer costs is most relevant in the less liquid off-the-run sector.

Das et al. (2003) suggest that there are three types of news shocks common to bond markets. These are intra-day calendar effects, public information effects and GARCH effects. Nevertheless, Das et al. points out that unlike stock and corporate bond markets, the government bond market is driven mainly by public information or macroeconomic news events. Consistent with Das et al. (2003), He and Nasser (1999) states that macroeconomic variable determines liquidity in bond markets. According to He and Nasser (1999), investors have become concerned with overall trends than with individual company fundamentals. Since both stocks and bonds are investment alternatives that compete for the investor's funds, the funds flow from one market to another due to a change in market situation and macroeconomic factors. He and Nasser (1999) pointed out that a number of studies have reported a negative relationship between long-term government bond rate and the stock prices in the US and UK. Davis (1999) concurs with He and Nasser (1999) and revealed movements of the economy and/or of interest rates as of overriding importance in the purchase of fixed-income securities. A rise in interest rates, due for instance, to monetary policy tightening may lead to a financial crisis, with liquidity collapses in security markets. In addition, in the presence of uncertainty, adverse surprises may trigger shifts in confidence, affecting markets and institutions more than appears, thus introducing the potential for a liquidity crisis.

Mukherjee and Atsuyuki (1995) propose that there is a positive relationship between exchange rates and stock prices. Exchange rate fluctuation is regarded as a critical factor for the foreign investor in the security market. The secondary security market liquidity increases when foreign currency appreciates. However, exchange rate fluctuation increases the exchange rate risk of the investment when foreign investors transfer their investment back to their mother countries. In South Africa, exchange rate fluctuation has a major impact on the secondary bond market liquidity considering that foreign investors play an active role in bond trading. Further, He and Nasser (1999) shows that economic prospects have increasingly affected the world's capital markets. It is suggested that inflationary pressures appear to play a key role in pushing up bond yields. Rutledge (1995) shows that growth in the world economy in the past caused intensive competition for capital, giving investors attractive alternatives to fixed-income instruments. However once inflation become more visible, the nominal risk-free rate was raised as interest rates rose. This affected the bond market negatively as bond prices fell due to high yields required by the investors. The same authors also goes on to point out that the fear of inflation has made many bond managers to shorten the duration of their portfolio and seek relative safety in the short to intermediate term sectors which in turn may also affect liquidity.

Chabchitrchaidol and Panyanukul (2005) suggest that adverse selection problems do impact on bond market liquidity as well. The authors suggest that adverse selection problems arise when informed traders who possess private information on the value of an asset not currently reflected in prices, are in the market. Such traders will want to trade only if the current ask price they face is below or the bid price above the fundamental value of the asset. There are two hypotheses under the adverse selection theory. Under the first hypothesis, suggested by Easley and O'hara (1992), higher trading volume will be a signal of the presence of informed traders and will result in increased spreads and hence a decrease on bond market liquidity. In this scenario, increased trading volume will be a signal to market makers that an information event has occurred. As uninformed traders, dealers specifically, always lose when dealing with informed traders, they have to recoup the losses from other investors by charging a larger bid-ask spread. Thus an unusual number of trades will result in the dealer widening the spread. According to this hypothesis therefore, higher trading volume will lead to higher spreads, thus reducing liquidity in the bond market. Under the second hypothesis, proposed by Harris and Raviv (1993), higher trading volume reveals an increase in liquidity, signalling higher overall market liquidity. In this case dealers will interpret that a volume shock is due to a change in the demands of "liquidity" traders such as through mutual fund redemption, and would not be expected to decrease liquidity and have little to no effect on bid-ask spread. 
However, Chabchitrchaidol and Panyanukul (2005) argue that existing models of adverse selection of the type discussed above have mainly looked at liquidity in equity markets, partly due to the fact that data is more easily available due to the nature of exchange-traded markets. As discussed, adverse selection models are based on the assumption that some investors have superior information on the payoff of the asset than others. However, this is unlikely to be the case for government bonds where cash flows are perfectly known (Lee et al., 1993). Even though it is unclear which of the two scenarios of adverse selection theory is appropriate for our case, it is clear that both volatility and trading volume are two of the main factors which determine spreads and hence liquidity in bond markets. The above literature shows that establishing the determinants of liquidity in the bond market has attracted academic attention. However much of the studies have been undertaken in developed countries and less have been done in developing countries due to underdevelopment of developing countries financial markets. This makes it interesting to examine the determinants of liquidity in the case of South Africa. This will enable us to identify policy variables that policy makers can focus upon to further deepen liquidity in this important segment of the market.

\section{Theoretical Framework and Model Specification}

Measuring Bond Market Liquidity: There is no consensus regarding the measure of liquidity in financial markets. However, the major proxies of liquidity are the bid-ask spread, trading volume, volatility, frequency, bond trading turnover, quote size, benchmark yield curve, average normal market size and number of market makers (CGFS, 1999). The choice of a liquidity measure depends on the development of the market. Two measures of liquidity, the volume of bonds traded and the bid-ask spread will be discussed in this section.

Liquidity Proxies: Trading volume is regarded by Abdourahmane and Tonny (2002) as the best measure in measuring breath. It is illustrated as follows:

$V=\sum P_{i}+Q_{i}$

Where: $\mathrm{V}=$ Rand Volume traded

$\mathrm{P}_{\mathrm{i}} \quad$ = Prices of the ith instrument traded during a specified period

$\mathrm{Q}_{\mathrm{i}} \quad$ = quantity

It is argued that markets that are deep are able to foster breath since larger orders can be divided into several smaller orders to minimize the impact of transaction prices. Abdourahmane and Tonny (2002) also point out that trading volume is traditionally used to measure the existence of numerous market participants and transactions. The other measure which is commonly used in the literature is the bid-ask spread. Abdourahmane and Tonny (2002) shows that the bid-ask spread is the absolute difference between bid and ask prices or it can be as a percentage. This is shown as follows:

$B A S=\left(P_{A}-P_{B}\right)$

Where: $\mathrm{BAS}=$ bid-ask spread

$$
\begin{aligned}
\mathrm{P}_{\mathrm{A}} & =\text { the ask price } \\
\mathrm{P}_{\mathrm{B}} & =\text { the bid price }
\end{aligned}
$$

According to Abdourahmane and Tonny (2002), ceteris paribus, the larger the trades that can be concluded at a quoted spread, the more depth and breadth the market have. However this measure of liquidity falls under the transaction costs measures. It is more appropriate in the case when determining the determinants of liquidity from a market microstructure perspective. The study will thus utilise the volume measure. This is consistent with Khama (2007) who advance a number of reasons as to why volume can be a better measure of liquidity in emerging markets. Amongst the reasons is the issue of bond trading not being frequent. This can be due to few players in the market unlike in the stock market. Also to capture data on bid-ask spread is complex. This makes the bid-ask spread suspect as there are few players which thus reduce competition. This therefore makes the bid-ask spread unreliable.

Model Specification: The study will focus only on the government bonds traded on the South African secondary bond market, because South African corporate and state enterprises bonds are not active in the secondary bond market. In addition, looking at government bonds when measuring liquidity is what is regarded as ideal. Choudhry (2010) proposes that any investigation into market liquidity should focus first on government bonds since with corporate bonds a number of other issues such as credit risk which is unrelated to liquidity may influence the results. This is consistent with Kamara (1994) who concluded 
that government bonds are fundamentally identical and credit-risk-free and thus could help focus on liquidity issues.

Restricted Vector Autoregression Model: In examining the determinants of liquidity in the South African bond market the study utilised the restricted Vector Autoregression model (VAR). This is due to the fact that the variables of analysis are simultaneously related. VAR models have proved to be a convenient method of summarizing the dynamic relationships among variables in such circumstances, since once estimated they can be used to simulate the response over time of any variable in the set to either an 'own' disturbance or a disturbance to any variable in the system (Ramaswamy \& Slok 1998). The VAR approach recognizes explicitly the simultaneity between bond market liquidity and its determinants (Benston \& Hagerman, 1974; Subrahmanyam, 1994), hence the need to treat each variable symmetrically and allow feedbacks among them. Restricted VAR models have also been found to be most suitable in capturing the feedback relationships among macroeconomic variables. Moreover, restricted VAR analysis is superior to a single equation approach for capturing the long-run equilibrium of variables while it incorporates an error correction mechanism to track the short run dynamics among the variables (Feasel, Kim \& Smith, 2001). More importantly, the structural version of the reduced-form VAR (which separates the influence of shocks from those of structure to capture the interactions among the variables of interest) is employed in the study. This method explicitly calculates the disturbances by inverting an estimated structural VAR of the relationship among the contemporaneous VAR residuals. The VAR model for the study is discussed as follows:

Assuming that $X_{t}$ is the $n \times 1$ vector of variables, the intra-impulse transmission process of which is to be captured by the study, the dimension of $X_{t}$ (that is $n$ ) is 7 , given the seven variables of the analysis. Using matrix algebra notations, an7-variable structural dynamic economic model for the study can be stated as:

$$
B X_{t}=\mu+\Gamma X_{t^{-1}}+\varepsilon_{t}
$$

Where $B$ is the matrix of variable coefficients

$\mathrm{X}_{\mathrm{t}}$ is the $7 \mathrm{x} 1$ vector of observations at time $\mathrm{t}$ of the variables of the study that is vector $\mathrm{X}$ is defined as

$$
\mathrm{X}_{\mathrm{t}}=\left(S Q R(V O L)_{t}, C P I_{t}, R E P_{t}, E X_{t}, S M I_{t}, F I P_{t}, \text { Dummy }\right)
$$

Also, $\quad \mu$ is the vector of constants

$\Gamma$ is a matrix polynomial of appropriate dimension

$\varepsilon_{\mathrm{t}}$ is a diagonal matrix of structural innovations that has zero means, constant variance, and are individually serially uncorrelated, i.e.

$\varepsilon_{\mathrm{t}} \sim(0, \Sigma)$

The ordering of the variables used in the study follows that discussed by Goyenko et al. (2011) in which variables are in the order in which they influence the other variables. Policy variables are placed first followed by macroeconomic variables since while financial markets respond to monetary policy, monetary policy is relatively exogenous to the financial system. The view of placing monetary policy instruments before financial variables are supported by Thorbecke (1997) and Chordia, Sarkar and Subrahmanyam (2003).

Estimation Techniques: The first step in our analysis is to test for stationarity of our variables. Gujarati (2003) suggest that a stationary stochastic process implies that the mean and variance are constant overtime, and the covariance between two periods depends only on the lag between the two time periods and not the actual time at which the covariance is computed. This implies therefore that a non-stationary time series will have a varying mean or varying variance or both. The statistical and time series properties of the data set were first carried out using the Augmented Dickey-Fuller (ADF) and PhillipsPerron (PP) to test for unit root. The ADF is given by the following equation:

$\Delta y_{t}=a_{0}+\gamma \mathrm{y}_{\mathrm{t}-1}+a_{2} t+\sum_{i=1}^{p} \beta_{i} \Delta \mathrm{y}_{t-1}+u_{t}$

The equation shows that: $\Delta Y_{t}=Y_{t}-Y_{t-1} ; \Delta Y_{t-1}=Y_{t-1}-Y_{t-2}$ etc. The test proceeds by testing the significance of the coefficient of Yt-1.The augmenting is done to remove possible autocorrelation among error terms. In the event that the calculated values are greater than the critical values, we reject the null and state that the variable is stationary. However, Mallik and Chowdhury (2001) and Ahmed and Mortaza (2005) point out that the PP test can properly distinguish between stationary and non-stationary time series with high degree of autocorrelation and presence of structural break. 
The test regression for the Phillips-Perron test is the AR(1) process given as:

$\Delta y_{t-1}=\alpha_{0}+\gamma \mathrm{y}_{t-1}+e_{t}$

As there is likely to be serial correlation in our explanatory variables, the PP test corrects for higher order serial correlation by adding lagged differenced terms on the right-hand side, this test makes a correction to the $t$ statistic of the coefficient $\gamma$ from the AR(1) regression to account for the serial correlation in $e_{t}$.

Having established the order of integration and stationarity of our variables, cointegration tests were undertaken. The Johansen cointegration test was employed in the study. The Johansen procedure produces two statistics, the likelihood ratio test based on maximal eigenvalue of the stochastic matrix and the test based on trace of the stochastic matrix. These statistics are then used to determine the number of cointegrating vectors. The test is based around an examination of the $\pi$ matrix, where $\pi$ can be interpreted as a long-run coefficient matrix. The test for cointegration between the variables is calculated by looking at the rank of the $\pi$ matrix via its eigenvalues. $\pi$ can be defined as the product of two matrices:

$$
\pi=\alpha \beta^{\prime}
$$

The matrix $\beta$ gives the cointegrating vectors, while $\alpha$ gives the amount of each cointegrating vector entering each equation of the VECM, also known as the 'adjustment parameter'.

Having established the number of cointegrating vectors, we proceeded with the estimation of the VECM. The VECM applies maximum likelihood estimation to VAR to simultaneously determine the long-run and short-run determinants of the dependent variable in the model.

This approach takes into account the short-term adjustments of the variables as well as the speed of adjustment of the coefficients. It therefore measures the speed at which the volume of bonds traded will revert to their equilibrium following a short term shock to it. In addition, this approach is appropriate for macroeconomics and financial data as it distinguishes between stationary variables with momentary effects and non-stationary variables with undeviating effects (Brooks, 2008).

The VECM specification has the following form:

$\Delta y_{\mathrm{t}}=\Pi y_{t-1}+\sum_{t=i}^{k} \Gamma_{i} \Delta y_{t-1}+\varepsilon_{k t} \mathrm{t}$

Where $y_{t}=\left(y_{1}+y_{2 t} \ldots.\right)$ is the $7 \times 1$ vector, $\Delta y_{t}$ are all $\mathrm{I}(0), \Gamma_{i}$ are the $7 \times 7$ coefficient matrices and

$\varepsilon_{k t} \quad$ are normally and independently distributed error terms.

Data and Definition of Variables: The study utilised monthly time series secondary data on government bonds with maturity of more than one year from 1995- 2009 (180 observations). For macroeconomic data (CPI, Repo rate, Stock Market Index and Foreign Investor participation) the main sources of data are the South African Reserve Bank (SARB) online statistical queries, Bond Exchange of South Africa's (BESA) online publications, Department of Trade and Industry's (DTI) Economic Statistics publications and Statistics South Africa online query. Volume $S Q R(V O L)$ represents the measure measures of liquidity. An increase in volume of bonds traded is an indication of liquidity in the market. CPI represents monthly inflation as measured by the Consumer Price Index $(C P I)$. A rise in the level of inflation which forces the monetary authorities to increase the repo rate will increase yields and hence cause price of bonds to fall. This is likely to decrease bond market liquidity. It is thus negatively related to bond market liquidity. $R E P$ represents the South African Reserve Bank (SARB) monthly repo rate, a tool which is currently used by the South African Reserve bank in monetary policy. An increase in the repo rate (contractionary monetary policy) results in high yields and hence low bond prices thus reducing bond appetite hence reduced liquidity. We thus expect a negative relationship between REP and volume of bonds traded. $E X$ represents exchange rate volatility. It is measured as the deviation from the average of four weekly exchange rate of the US dollar in terms of the rand. Exchange rate volatility leads to uncertainty in the foreign exchange market. This adds to risk premium to the forward market transactions and these uncertainties adversely affect the foreign participation in domestic bond markets and hence the development of the benchmark yield curve. The exchange rate is of importance in the case of South Africa since foreign buyers are active participants in our bond market. We expect a negative relationship between EX and volume of bonds traded. SIM is the monthly Johannesburg All share stock market Index. Theoretically, shares are another form of investment which competes for the same investor's funds. An 
investment in shares may mean disinvestment from bonds hence reduced liquidity. FIP represents net foreign buyers of bonds on BESA. An increase in Foreign Investor Participation (FIP) results in the broadening of the investor base and enhanced liquidity in the secondary bond market. We thus expect a positive relationship between FIP and bond market liquidity. The study will also incorporate a dummy variable to capture the impact of the global financial crisis on the bond market liquidity in South Africa. It will assume a value of 0 prior to May 2007 and a value of 1 from June 2007. It will be expected to have a negative effect on bond market liquidity.

\section{Econometric Procedure and Results}

Unit Root Tests Results: Time series properties of the data were carefully evaluated through the Augmented Dickey Fuller (ADF) and Phillip-Peron (PP) tests. The results are reported in table 2.

Table 2: Unit Root tests (Level Series)

\begin{tabular}{lllll}
\hline Series & $\begin{array}{l}\text { Augmented Dickey Fuller Test (ADF) } \\
\text { Constant }\end{array}$ & Constant and Trend & $\begin{array}{l}\text { Phillips-Peron (PP) } \\
\text { Constant }\end{array}$ & Constant and Trend \\
\hline Vol & -0.002986 & -0.970015 & -0.733840 & -1.324218 \\
CPI & -0.001788 & -0.970015 & $-0.875225^{*}$ & -0.851235 \\
SMI & 0.125282 & -1.51625 & -0.223969 & -1.883499 \\
FIP & -0.034536 & -0.396052 & -0.547456 & -0.451967 \\
EX & -0.103459 & -0.103143 & -1.960873 & -1.875754 \\
REP & -0.040503 & -0.299520 & -0.040503 & -0.299520 \\
\hline
\end{tabular}

Notes:

i. $\quad{ }^{* * *}\left(0.01\right.$ level of significance), ${ }^{* *}(0.05$ level of significance $)$ and ${ }^{*}(0,1$ level of significance.

ii. Maximum Bandwidth for the PP test has been decided on the basis of Newey-West (1994)

iii. The ADF and PP tests are based on the null hypothesis of unit roots.

Source: Author's Computation using Eviews 7 Econometric Package

Table 3: Unit Root test (First Difference Series)

\begin{tabular}{llllll}
\hline Series & \multicolumn{2}{l}{$\begin{array}{l}\text { Augmented Dickey Fuller Test (ADF) } \\
\text { Constant }\end{array}$} & $\begin{array}{l}\text { Constant } \\
\text { Trend }\end{array}$ & and & \multicolumn{2}{l}{ Phillips-Peron (PP) } & Constant & $\begin{array}{l}\text { Constant } \\
\text { Trend }\end{array}$ & and & Decision \\
\hline$\Delta$ Vol & $-14.99727^{* * *}$ & $-15.00365^{* * *}$ & $-19.72108^{* * *}$ & $-19.72031^{* * *}$ & $\mathrm{I}_{(1)}$ \\
$\Delta \mathrm{CPI}$ & $-7.542908^{* * *}$ & $-7.534760^{* * *}$ & $-7.601983^{* * *}$ & $-7.591804^{* * *}$ & $\mathrm{I}_{(1)}$ \\
$\Delta \mathrm{SMI}$ & $-12.29702^{* * *}$ & $-12.32784^{* * *}$ & $-12.61948^{* * *}$ & $-12.63192^{* * *}$ & $\mathrm{I}_{(1)}$ \\
$\Delta \mathrm{FIP}$ & $-14.07829^{* * *}$ & $-14.09080^{* * *}$ & $-18.47758^{* * *}$ & $-18.49781^{* * *}$ & $\mathrm{I}_{(1)}$ \\
$\Delta \mathrm{EX}$ & $-9.071762^{* * *}$ & $-9.086775^{* * *}$ & $-9.038862^{* * *}$ & $-9.142365^{* * *}$ & $\mathrm{I}_{(1)}$ \\
$\Delta \mathrm{REP}$ & $-4.459287^{* * *}$ & $-4.441802^{* * *}$ & $-8.703764^{* * *}$ & $-8.681126^{* * *}$ & $\mathrm{I}_{(1)}$ \\
\hline
\end{tabular}

Notes:

i. $\quad * * *(0.01$ level of significance $), * *(0.05$ level of significance $)$ and $*(0,1$ level of significance.

ii. $\Delta$ is the first difference symbol

Source: Author's Computation using Eviews 7 Econometric Package

Table 2 and 3 indicates that all variables were regarded as non-stationary at their levels at $5 \%$ level. The variables were tested for stationarity at first differences (Table 3). The results indicated that all variables are stationary. The results confirmed therefore that differencing once was all that was required to bring these variables to stationarity at all levels of significance. This suggests that our variables are integrated of order one I(1). Having established the order of integration and time series properties of the variables, cointegration tests were conducted. The optimal lag order was determined empirically. The results are reported in table 4. 
Table 4: Lag Selection criteria

\begin{tabular}{lllllll}
\hline Lag & LogL & LR & FPE & AIC & SC & HQ \\
\hline 0 & -4686.177 & NA & $2.27 \mathrm{e}+28$ & 82.31889 & 82.46290 & 82.37733 \\
1 & -3948.172 & $66.58531^{*}$ & $5.02 \mathrm{e}+23^{*}$ & 70.00302 & $71.01109^{*}$ & $70.41214^{*}$ \\
2 & -3880.151 & 120.5291 & $1.83 \mathrm{e}+22$ & 69.44124 & 71.31337 & 70.20103 \\
3 & -3840.199 & 1385.377 & $5.51 \mathrm{e}+22$ & $69.37192^{*}$ & 72.10812 & 70.48239 \\
4 & -3814.874 & 39.54267 & $6.81 \mathrm{e}+22$ & 69.55920 & 73.15946 & 71.02034 \\
5 & -3783.873 & 45.14192 & $7.74 \mathrm{e}+22$ & 69.64690 & 74.11122 & 71.45872 \\
6 & -3746.432 & 50.57882 & $8.03 \mathrm{e}+22$ & 69.62161 & 74.95000 & 71.78410 \\
7 & -3715.716 & 38.25941 & $9.63 \mathrm{e}+22$ & 69.71432 & 75.90677 & 72.22749 \\
8 & -3675.057 & 46.36587 & $1.00 \mathrm{e}+23$ & 69.63258 & 76.68909 & 72.49642 \\
\hline
\end{tabular}

* indicates lag order selected by the criterion

LR: sequential modified LR test statistic (each test at 5\% level), FPE: Final prediction error, AIC: Akaike information criterion, SC: Schwarz information criterion, HQ: Hannan-Quinn information criterion.

Based on several criteria (AIC, SIC, FPE, LR and HQ), a lag order of 1, which produced a stable VECM, was selected. The Johansen test proved evidence of three cointegrating vectors.

Table 5: Johansen cointegration Test Results

\begin{tabular}{lllllll}
\hline $\begin{array}{l}\text { Hypothesized } \\
\text { No. of CE(s) }\end{array}$ & Eigenvalue & $\begin{array}{l}\text { Trace } \\
\text { Statistic }\end{array}$ & $\begin{array}{l}\mathbf{0 . 0 5} \\
\text { Critical } \\
\text { Value }\end{array}$ & $\begin{array}{l}\text { Max-Eigen } \\
\text { Statistic }\end{array}$ & $\begin{array}{l}\mathbf{0 . 0 5} \\
\text { Critical } \\
\text { Value }\end{array}$ & Prob.** $^{*}$ \\
\hline None $^{*}$ & 0.7532 & 226.58 & 159.52 & 71.371 & 52.362 & 0.0002 \\
At most 1 & 0.6136 & 155.21 & 125.61 & 48.505 & 46.231 & 0.0281 \\
At most 2 & 0.5511 & 106.71 & 95.753 & 40.854 & 40.077 & 0.0408 \\
At most 3 & 0.4278 & 65.857 & 69.818 & 28.476 & 33.876 & 0.1924 \\
At most 4 & 0.3248 & 37.381 & 47.856 & 20.032 & 27.584 & 0.3389 \\
At most 5 & 0.1818 & 17.348 & 29.7970 & 10.236 & 21.131 & 0.7221 \\
At most 6 & 0.1224 & 7.1120 & 15.4947 & 6.6591 & 14.264 & 0.5302 \\
At most 7 & 0.0088 & 0.4529 & 3.84146 & 0.4529 & 3.8414 & 0.5009 \\
\hline
\end{tabular}

Notes:

i. $\quad$ Both Trace test and Max-Eigen Statistic indicate 3 Cointegrating equations at 0.05 level of significance.

ii. $\quad *$ denotes rejection of the null hypothesis at 0.05 level of significance

iii. The series of estimation are $\operatorname{sqr}(\mathrm{vol}), \operatorname{vol}(\mathrm{x}), \mathrm{cpi}, \mathrm{rep}, \mathrm{smi}$, fip.

iv. Critical values are from Mackinnon-Haug-Michelis (1999).

v. The results are based on the assumption of a constant linear trend in the data with optimal lag length 2.

Source: Author's Computation using Eviews 7 Econometric Package

The Johansen cointegration test indicates that there are three cointegrating equations. This thus suggests that there is a long-term relationship between the variables of interest. Having established cointegration, a Vector Error Correction Model (VECM) normalised on the volume of bonds traded was estimated and the long run regression results are provided below:

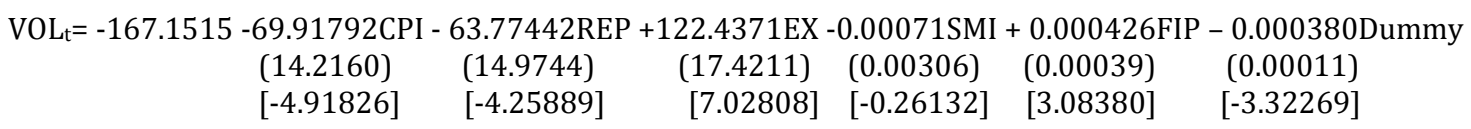

Notes:

$[-4.91826] \quad[-4.25889] \quad[7.02808] \quad[-0.26132] \quad[3.08380] \quad[-3.32269]$

() standard errors

[] t-statistics

The empirical results show that all macroeconomic variables (except stock market index) are significant in the long-run. CPI is significant and correctly signed. This is consistent with the apriori expectations. An increase in the inflation rate results in the central bank increasing the repo rate to reduce inflationary 
pressures. An increase in the repo rate will thus lead to an increase in the risk-free rate and hence a decrease in the bond price since there is a negative relationship between bond price and yield. This is likely to result in a reduction in the volume of bonds traded in the secondary bond market as bonds will not be a "lucrative" investment. This is consistent with He and Nasser (1999), Andritzky et al. (2007) and George and Longstaff (1993). The exchange rate (EX) is correctly signed and significant. This again conforms to the apriori expectations. The appreciation of the ZAR against the US dollar will mean an increase in bond returns. The foreign investor participation (FIP) variable again is significant and positively signed. An increase in the number of foreign investors means an increase in the number of participants in the bond market and hence liquidity. This can be attributed to the role played by foreign investors in the South African bond market as they are net buyers of bonds.

The stock market index (SMI) even though insignificant, is negatively related to the volume of bonds traded. This is consistent with theory and empirical evidence as pointed by He and Nasser (1999). Theoretically bonds and stocks are regarded as securities which investors can invest in. Given that there is a budget constraint, an increase in funds allocated to bonds means a reduction in funds allocated to equities. The repo rate (REP) is significant and correctly signed. The negative impact of the repo rate on market bond liquidity can be best interpreted with reference to institutional investors who are very sensitive to changes in the inter-bank rate, which determines the return on short-term investment. Many of the investors are mutual funds and investment companies who must invest their limited funds in the securities for the best use. When the repo rate increases, the short-term investment become more attractive than bonds, institutional investors would invest more funds in short-term investment instead of bonds. Thus, the investors would purchase fewer bonds when the repo rate is high. The results on the dummy variable are also consistent with the apriori expectations. The empirical results reveal a statistical significant negative relationship between the measure of the crisis and bond market liquidity in South Africa. This suggests that the global financial crisis had a negative impact on the liquidity in the bond market in South Africa. Having established the presence of cointegration, the VECM was estimated to determine the speed of adjustment as well as well as the interaction between the variables in the shortterm. The results are illustrated in table 6 .

Table 6: The Vector Error Correction Model

\begin{tabular}{lllllllll}
\hline $\begin{array}{l}\text { Error } \\
\text { Correction: }\end{array}$ & SQR(VOL) & D(VOLX) & D(CPI) & D(REP) & D(EX) & D(SMI) & D(FIP) & D(Dummy) \\
\hline CointEq1 & -0.3798 & -0.0033 & -0.0014 & -0.0013 & 0.0009 & -0.2263 & 105.64 & 0.0221 \\
& $(0.1234)$ & {$[0.0013)$} & {$[0.0009)$} & {$[0.0005)$} & {$[0.0005)$} & {$[2.2298)$} & $(66.94)$ & $(0.0324)$ \\
& {$[-1.059]$} & {$[-2.495]$} & {$[-1.599]$} & {$[-2.664]$} & {$[1.9125]$} & {$[-0.1015]$} & {$[1.578]$} & {$[0.6820]$} \\
\hline
\end{tabular}

The VECM indicates that the speed of adjustment of the volume variable is $38 \%$. This shows that in the case of disequilibrium, about $38 \%$ of it is corrected within a month. The short-term relationship between variables was also illustrated by means of the correlation matrix shown in Table 4.

Table 7: Correlation matrix

\begin{tabular}{llllllll}
\hline & $\begin{array}{l}\text { SQR } \\
\text { (VOL) }\end{array}$ & CPI & REP & EX & SMI & FIP & Dummy \\
\hline VOLUME & 1.0000 & & & & & & \\
CPI & -0.1228 & 1.0000 & & & & & \\
REP & -0.0031 & 0.2589 & 1.0000 & & & & \\
EX & -0.2134 & -0.4510 & -0.2118 & 1.0000 & & & \\
SMI & -0.2937 & 0.0435 & -0.3524 & -0.2545 & 1.0000 & & \\
FIP & 0.8938 & -0.1254 & 0.2553 & -0.0586 & 0.2321 & 1.0000 & \\
Dummy & -0.1250 & 0.2345 & 0.3254 & 0.1245 & -0.2135 & -0.2134 & 1.0000 \\
\hline
\end{tabular}

Source: Author's Computation using EVIEWS 7 Econometric Software

Table 7 presents the contemporaneous relations between innovations in the variables. It is evident that innovations in the REP are negatively related with liquidity of the South African bond market as measured volume of bonds traded. This is consistent with results of Goyenko et al. (2011). The same 
applies to CPI, EX and SMI which drain liquidity in the bond market as indicated in the correlation matrix. The negative correlation between EX and Volume points to the negative effects of exchange rate volatility. On the other hand, shocks on FIP are positively correlated with liquidity in the South African bond market. In consonance with theoretical expectations, the correlation between VOL and FIP which is the highest supports Shanaka (2010)'s propositions that foreign investors do play an important role in enhancing liquidity in secondary bond markets.

Impulse Response: The impulse response functions were conducted to analyse the short-term interaction between the variables. The impulse responses show the dynamic response of each variable to a one-period standard deviation shock to the innovations of each variable. The interpretation of the impulse response function does take into account the use of the first differencing of the variables as well as the vector error correction estimates. Thus, a one-time shock to the first difference in a variable is a permanent shock to the level of that variable. The results are reported in the appendix. Of particular interest in this study is the dynamic response of Volume (SQR (VOL)) of bonds traded to themselves and to innovations in each macroeconomic variable. The response of SQR(VOL) to REP is consistent with the apriori expectation as innovations associated with an increase in the repo rate decreases the volume of bonds traded in the fourth period and remain below the base line. The same applies to innovations in CPI which negatively impacts the liquidity of the bond market. Innovations in FIP results in a mixed response in bond market liquidity. On the other hand the results indicate that the shock from the crisis was significant within the first month, however it died down within three months after the shock. This is consistent with the South African experience in which the bond market boomed at the height of the crisis though initially it constrained liquidity in the market.

Variance Decomposition: The variance decomposition was also constructed to analyse the short-term interaction between the variables. Brooks (2008) argues that variance decompositions give the proportion of the movement in the dependent variables that are due to their own shocks, versus shocks to the other variables. A shock to the $i^{\text {th }}$ variable will directly affect that variable and will be transmitted to all of the other variables in the system through the dynamic structure of the VAR. The results are reported in table 8 .

Table 8: Variance Decomposition

\begin{tabular}{lllllllll}
\hline Period & S.E. & VOL & CPI & REP & EX & SMI & FIP & Dummy \\
\hline 1 & 243274.9 & 88.79173 & 0.000000 & 0.000000 & 0.000000 & 0.000000 & 0.000000 & 0.000000 \\
5 & 466966.6 & 76.14309 & 3.724590 & 2.665595 & 0.230561 & 0.843141 & 0.758702 & 0.144287 \\
10 & 645046.0 & 75.52186 & 4.314766 & 2.692886 & 0.292055 & 0.517940 & 0.419962 & 0.083101 \\
15 & 784358.4 & 75.47185 & 4.461891 & 2.643943 & 0.318842 & 0.394271 & 0.288390 & 0.057006 \\
20 & 902507.4 & 75.42723 & 4.538723 & 2.630433 & 0.334355 & 0.332058 & 0.221644 & 0.043280 \\
24 & 986902.4 & 75.40366 & 4.578295 & 2.624119 & 0.342146 & 0.300484 & 0.187867 & 0.036339 \\
\hline
\end{tabular}

As indicated in table 8, the variance decomposition of the volume of bonds traded were constructed with a 24 month horizon using Choleski decomposition method in order to identify the most effective instrument to use in targeting each variable of interest. This helps in separating innovations of the endogenous variables into portions that can be attributed to their own innovations and to innovations from other variables. Results indicates that the predominant sources of variations in the volume of bonds traded of between 89 per cent and 75 per cent of the forecast errors is own shocks. Innovations in CPI and REP are other important sources of forecast error variance in SQR(VOL) as far as macroeconomic factors are concerned. Consumer Price Index (CPI) on the other hand increases from the short-term, through the medium and long-term. FIP, SMI EX and the dummy variable are relatively insignificant throughout the twenty four months. The results suggest that own shock explains the greater part of the variability of bond market liquidity as measured by the volume of bonds traded.

VEC Granger Causality/ Block Exogenity Wald Test: The interest of this section is to examine the causal relationships between the volume of bonds traded and foreign investor participation, CPI and the repo rate. The results are presented in table 9. 
Table 9: VEC Granger Causality Tests Results

\begin{tabular}{lcll}
\hline $\begin{array}{l}\text { Dependent variable: Volume of Bonds Traded } \\
\text { Excluded }\end{array}$ & Chi-sq & Df & Prob. \\
\hline FIPB & 4.090821 & 2 & 0.0293 \\
EX & 5.530427 & 2 & 0.0170 \\
REPO_RATE & 4.345690 & 2 & 0.0413 \\
All & 6.695495 & 6 & 0.0099 \\
\hline
\end{tabular}

Of great importance in the study was to analyse the causal relationship between the volume of bonds traded and the selected variables. The results suggest that there is evidence of a unidirectional causality from foreign investor participation, the exchange rate and the repo rate. These results are in consonance with the previous estimations. Jointly also the results are significant too. This emphasises the importance of macroeconomic stability in South Africa to enhance liquidity in the South African bond market.

VAR Diagnostic Checks: The model employed in the study was subjected to rigorous tests to further examine the validity of the results. The results are reported in table 10 and Figure 1.

Table 10: Diagnostics Tests

\begin{tabular}{llll}
\hline Test & Test statistic & p-Value & Conclusion \\
\hline Jarque-Bera & 18.55907 & 0.1520 & Residuals are normally distributed \\
Breusch-Godfrey & 0.815606 & 0.6651 & Residuals are not Serially Correlated. \\
ARCH LM & 71.37372 & 0.2461 & Residuals are Homoscedastic \\
\hline
\end{tabular}

Table 10 indicates that the model does not suffer from non-normality. Therefore the null hypothesis of normality cannot be rejected. The null hypothesis of no serial correlation could not also be rejected. The result of the White Heteroskedasticity (no cross terms) p-value is 0.1415 implying that the null of homoskedastic residuals cannot be rejected. The AR Roots graph in figure 1 indicates that all roots lie inside the unit circle which indicates that our restricted VAR is stable.

Figure 1: Diagnostic Tests for the Stability of the VEC Model

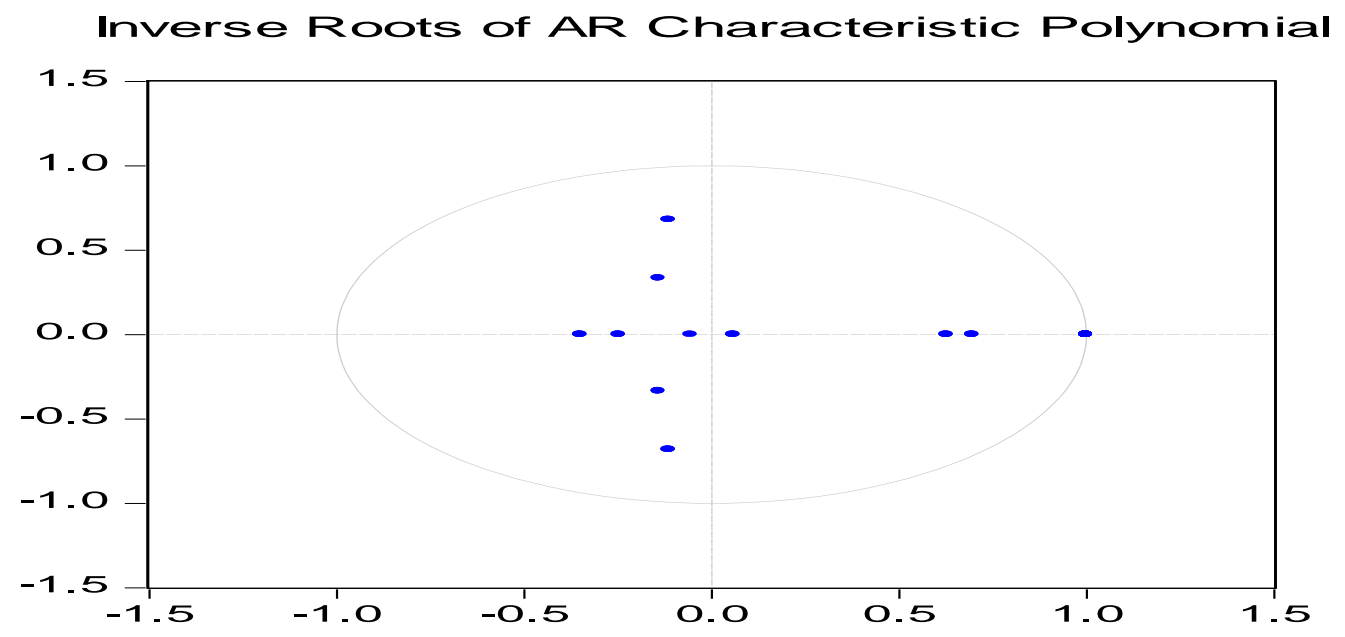

\section{Conclusion}

The study analysed the determinants of liquidity in the South African bond market employing the Johansen cointegration test and the VECM model. The empirical results suggest that volume of bonds traded is negatively related to innovations in inflation, repo rate, exchange rate volatility and the stock market index. On the other hand the volume of bonds traded was seen to be positively related to an increase in foreign investor participation. These results were consistent with theoretical predictions as 
well as prior empirical analysis (Goyenko et al., 2011; He and Nasser, 1999). In terms of policy choice, authorities should keep inflation at low and stable levels as well as maintain a stable currency. These will boost bond market liquidity. Removing restrictions on foreign investor activities should be encouraged as their activities do have a positive effect on bond market liquidity. The negative relationship between the stock market index and volume of bonds suggest that the bond market as an investment is affected by developments in the stock market. Policy makers must therefore be aware of the implications of policy measures that promote one market at the expense of the other depending on the stage of development of the financial market and the structure of the economy.

\section{References}

Abdourahmane, S. \& Tonny, I. (2002). Measuring Liquidity in Financial Markets. IMF Working Paper, 2, 164.

Adelegan, O. J. (2009). The Derivatives market in South Africa: Lessons for Sub-Saharan African Countries. IMF Working Paper, WP/09/196

Ahmed, S. \& Mortaza, G. (2005). Inflation and Economic Growth in Bangladesh, 1981- 2005, Policy Analysis Unit (PAU) Working Paper0604.

Ambrosi, M. (2009). David and Goliath: the South African debt market, [Online]. Available on <http//http://www.world-exchanges.org/news-views/views/david-and-goliath-south-africa debt-market>. Accessed on 20/03/2010.

Andritzky, J. R., Bannister, G. J. \& Tamirisa, N. T. (2007). The Impact of Macroeconomic Announcements on Emerging market Bonds, IMF Working Paper 05/83.

Asian Development Bank. (2005). Domestic Bond markets. Chapter 4: Liquidity [Online]. Available on <http// http://www.adb.org/Projects/Apec/DBM/chapter4.asp>. Accessed on 20 November 2010.

Bank of International Settlements. (2011). Quarterly Review detailed statistical Annex, BIS Papers June 2011

Benston, G. \& Hagerman, R. (1974). Determinants of bid-asked spreads in the over-the counter market. Journal of Financial Economics, 1, 353-364.

Bond Exchange of South Africa. (2005). Developing a capital market in Africa: and its implications for infrastructure development on the continent, 17 October. pp 4-14.

Bond Exchange of South Africa. (2006). Market regulation report: Annual report 2006, [Online] Available: http://www.bondexchange.co.za/besa/action/media/downloadFile?media_fileid=6834Accesse d on November 15 November 2010.

Bond Exchange of South Africa Online Publications. (2010). Available on <http//www.besa.co.za> Accessed on 25 April 2010.

Borio, C. (2000). Market liquidity and stress: selected issues and policy implications. BIS Quarterly Review, $3,38-51$.

Brooks, C. (2008). Introductory Econometrics for Finance, Cambridge University Press

Chabchitrchaidol, A. \& Panyanukul, S. (2005). Key Determinants of Liquidity in the Thai Bond Market, Bank of Thailand: [Online] available on <http// www.bis.org/repofficepubl/arpresearch>. Accessed on 25/03/2010.

Chordia, T., Sarkar, A. \& Subrahmanyam, A. (2003). An Empirical Analysis of Stock and Bond Market Liquidity, Federal Reserve Bank of New York Staff Reports, No. 164.

Choudhry, M. (2010). Measuring bond market liquidity: devising a composite aggregate liquidity score. Applied Financial Economics, 20, 12, 955-973, First published on: 03 June 2010 (iFirst) Committee on The Global Financial System 1999. Market Liquidity: Research Findings and Selected Policy Implications, Bank of International Settlements.

Committee on the Global Financial System. (1999). Market Liquidity: Research Findings and Selected Policy Implications, Bank of International Settlements (BIS)

Das, S. R., Ericsson, J. \& Kalimipalli, M. (2003). Liquidity and the Bond Markets. Journal of Investment Management, 1(4), 95-103.

Davis, E. P. (1999). Financial Data needs for Macro prudential Surveillance-What are the key indicators of risks to domestic financial stability? Bank of England

Easley, D. \& O'hara, M. (1992). Time and the Process of Security Price Adjustment. Journal of Finance, 47, $577-605$.

Faure, A. P. (2008). SAIFM: The Bond Market, Cape Town: Quoin Institute

Faure, A. P. (2007). SAIFM: The Bond Market. Cape Town: Quoin Institute. 
Feasel, E., Kim, Y. \& Smith, S. C. (2001). A VAR Approach to Growth Empirics: Korea. Review of Development Economics, 5(3), 421-432.

Fitch Ratings. (2009). Fitch: South African Bond Market Compares Well to Emerging Market Peers, [Online]. Available on <http//fitchratings.com>. Accessed on 20/02/2010.

Fujimoto, A. (2004). Macroeconomic Sources of Systematic Liquidity, Working Paper, Yale University.

Garcia, G. (1989). The Lender of Last Resort in the wake of Crash. American Economic Review, 79, 151 155.

George, T. J. \& Longstaff, F. A. (1993). Bid--Ask Spreads and Trading Activity in the S\&P 100 Index Options Market. Journal of Financial and Quantitative Analysis, 28, 381-97

Gravelle, T. (1998). Buying back government bonds: Mechanics and other considerations, Working Paper, No 98-9, Bank of Canada

Greubel, G. (2008). Developing Capital Markets in Africa in Financial Innovation and Emerging markets, Federal Ministry for Economic Cooperation and Development

Gujarati, D. N. (2003). Basic econometrics (4e). New York: McGraw-Hill Inc.

Goyenko, R., Subrahmanyam, A. \& Ukhov, A. (2011). The term structure of bond market liquidity and its implications for expected bond returns. Journal of Financial and Quantitative Analysis, 46(1), 111-139.

Harris, M. \& Raviv, A. (1993). Differences of Opinion make a Horse Race. Review of Financial Studies, 6, 473-506.

Hove, T. (2008). Bond Market Development in Emerging Economies: A Case Study of the Bond Exchange of South Africa (BESA). Masters in Commerce (Financial Markets). Rhodes University.

He, W. \& Nasser, T. (1999). An Empirical Study on the Factors Affecting Bond Liquidity in the Thai Secondary Bond Market, [Online]. Available on $<$ http//www.journal.au.edu/abac_journal/dec99/wei_tareque_f.html>. Accessed on 26/04/2010.

Jones, A. (2007). BESA: overview of the capital markets. BESA. 20 July. pp 1-31.

Kamara, A. (1994). Liquidity, taxes and short-term treasury yields. Journal of Financial and Quantitative Analysis, 29, 403-17.

Khama, W. O. (2007). Determinants of Liquidity of the Government Bond Market vis-a-vis Investors Participation: The Case of Tanzania, Unpublished Master's Thesis: University of Botswana.

Lee, C. M., Belinda, M. \& Mark, J. R. (1993). Spreads, Depths, and the Impact of Earnings Information: An Intraday Analysis. The Review of Financial Studies, 6(2), 345-374

Mallik, G. \& Chowdhury, A. (2001). Inflation and Economic Growth: Evidence from Four South Asian Countries. Asia-Pacific Development Journal, 8(1).

Mackinnon, J. G., Haug, A. A. \& Michelis, L. (1999). Numerical distribution functions of likelihood ratio tests for cointegration. Journal of Applied Econometrics, 14, 563-577

Mminele, A. D. (2009). Recent economic Developments in South Africa, Bank of International Settlements

Mukherjee, K. T. \& Atsuyuki, N. (1995). Dynamic Relations between Macroeconomic Variables and the Japanese Stock Market: An Application of a Vector Error Correction Model. Journal of Financial Research, 18(2), 223-37

Newey, W. K. \& West, K. D. (1994). Automatic lag selection in covariance matrix estimation. Review of Economic Studies, 61, 631-653.

Ramaswamy, R. \& Slok, T. (1998). The Real Effects of Monetary Policy in the European Union: What are the Differences? IMF Staff Papers, 45(2), 374-396.

Rutledge, J. (1995). History lesson. Forbes, 155, 118

Shanaka, J. P. (2010). Foreign Participation in Emerging Market's Local Currency Bond Markets, International Monetary Fund, WP/10/88.

South African Reserve Bank. (2010). Financial stability Review, September 2010

Subrahmanyam, A. (1994). Circuit Breakers and Market Volatility: A Theoretical Perspective. Journal of Finance, 49, 237-254.

Thorbecke, W. (1997). On stock market returns and monetary policy. Journal of Finance, 52, 635-654. 


\section{Appendix 1}

Response of VOL to VOL

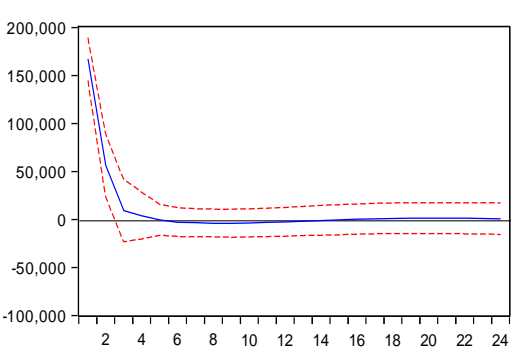

Response of VOL to EX

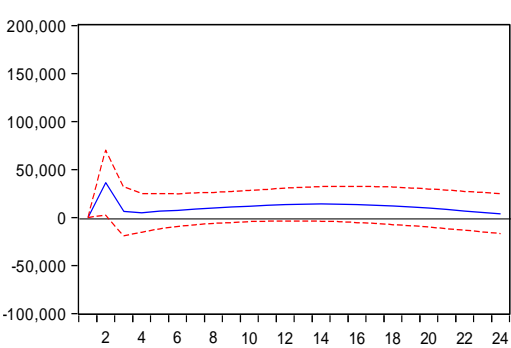

Response of VOL to DUMMY

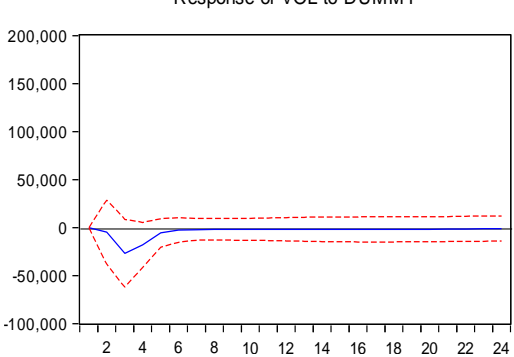

Response to Cholesky One S.D. Innov ations \pm 2 S.E.

Response of VOL to $\mathrm{CPI}$

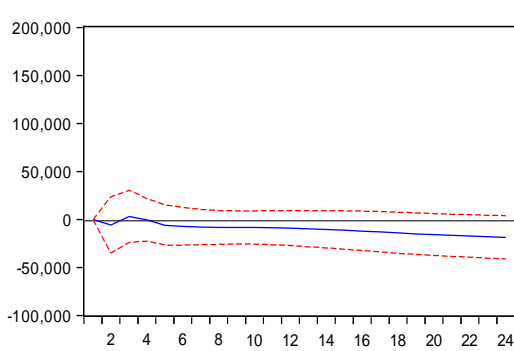

Response of VOL to SEM

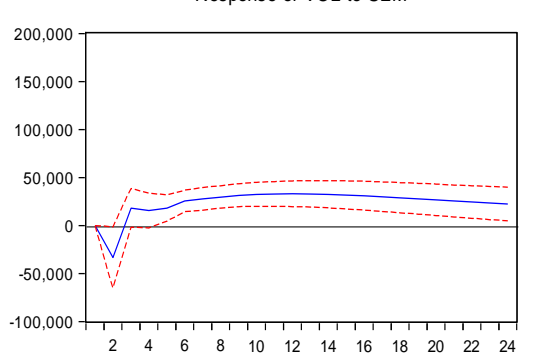

Response of VOL to REP

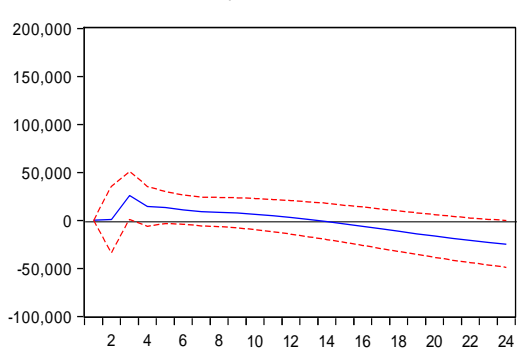

Response of VOL to FIP

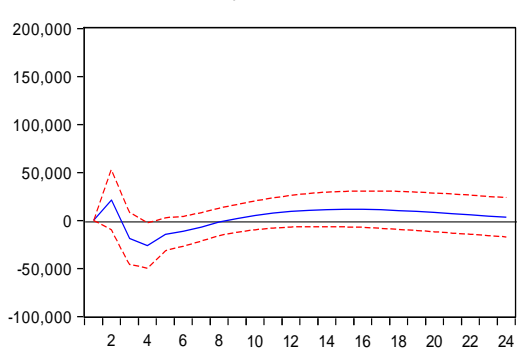

